\title{
Adult morgagni hernia: a single center experience of 5 cases and review of literature
}

\author{
Cihan Ağalar ${ }^{1}$ (ID), Koray Atila ${ }^{1}$ (ID), Naciye Çiğdem $\operatorname{Arslan}^{2}$ (iD), Zekai Serhan Derici ${ }^{1}$ (ID), Seymen Bora ${ }^{1}$ (iD) \\ ${ }^{1}$ Department of General Surgery, Dokuz Eylul University School of Medicine, Izmir, Turkey \\ ${ }^{2}$ Department of General Surgery, Istinye University School of Medicine, Istanbul, Turkey
}

\begin{abstract}
Morgagni hernia is a rare congenital anomaly arising through the fusion defect between the septum transversum and sternum. Diagnosis is usually confusing as the presentation may be asymptomatic as well as with respiratory symptoms, abdominal and/or retrosternal pain, abdominal fullness or gastrointestinal obstruction. In this paper, we discussed the clinical presentation and management of this rare situation with five consecutive cases. Between 2009 and 2015, five cases underwent surgery for Morgagni hernia (3 laparoscopic and 2 open repair); one patient had recurrent hernia after 7 months from laparoscopic surgery. This case is the first recurrence in the literature after laparoscopic repair in an adult group. In Morgagni hernias, the only treatment is surgery, which can be performed by transthoracic, transabdominal, laparoscopic or thoracoscopic approaches. The issues of using mesh and reducing the hernia sac are still controversial.
\end{abstract}

Keywords: Laparoscopic repair, morgagni hernia, diafragmatic hernia

Cite this article as: Ağalar C, Atila K, Arslan NÇ, Derici ZS Bora S. Adult morgagni hernia: a single center experience of 5 cases and review of literature. Turk J Surg 2019; 35 (4): 321-324.

\section{Corresponding Author}

Cihan Ağalar

E-mail: cihanagalar@hotmail.com

Received: 29.06.2017

Accepted: 09.08.2017

Available Online Date: 16.12 .2019

O Copyright 2019 by Turkish Surgical Society Available online at www.turkjsurg.com

DOI: 10.5578/turkjsurg.3929

\section{INTRODUCTION}

Morgagni hernia was first described by an Italian anatomist and pathologist Giovanni Morgagni in $1769(1,2)$. This para-retrosternal defect between the septum transversum and sternum is called foramen larrey or foramen Morgagni (1). Incidence is 1/2000-5000 and Morgagni hernia constitutes 3-4\% of all congenital diaphragmatic hernias (3). Abdominal organs herniate to the thorax through a retrosternal diaphragmatic defect from the right side in $90 \%$ of the cases. Pericardium has been considered to be responsible for the decreased incidence of left-sided Morgagni hernia. Bilateral cases have been reported uncommonly (4). Increased intraabdominal pressure have been associated with Morgagni hernia, especially in the adult age group.

Chest x-ray and thorax computed tomography (CT) are helpful in diagnosis. Omentum, transvers colon and less often stomach and small bowel are herniating organs to thorax. Treatment is surgery which can be performed with transthoracic, transabdominal, laparoscopic or thoracoscopic approaches.

Our aim in this study was to discuss the clinical presentation and management of these rare cases in adults.

\section{CASE REPORTS}

All patients gave their informed consent about the publishing of their operation data and documents for scientific purposes.

\section{Case 1}

A 74-year-old female patient presented with abdominal pain, nausea, vomiting, and anorexia. Her chest x-ray showed a right paracardiac opacity (Figure 1A). Morgagni's hernia was suspected and confirmed by thoracoabdominal CT (Figure 1B). The patient was operated on through an upper midline incision and found to have bilateral Morgagni hernia. There were hernia sacs on both sides (Figure 1C). The left one contained the stomach and large bowel and the right one contained the omentum. The contents were reduced and the sacs were not excised. Repair of both defects was carried out using expanded polytetrafluoroethylene (E-PTFE) mesh (Figure 1D). 

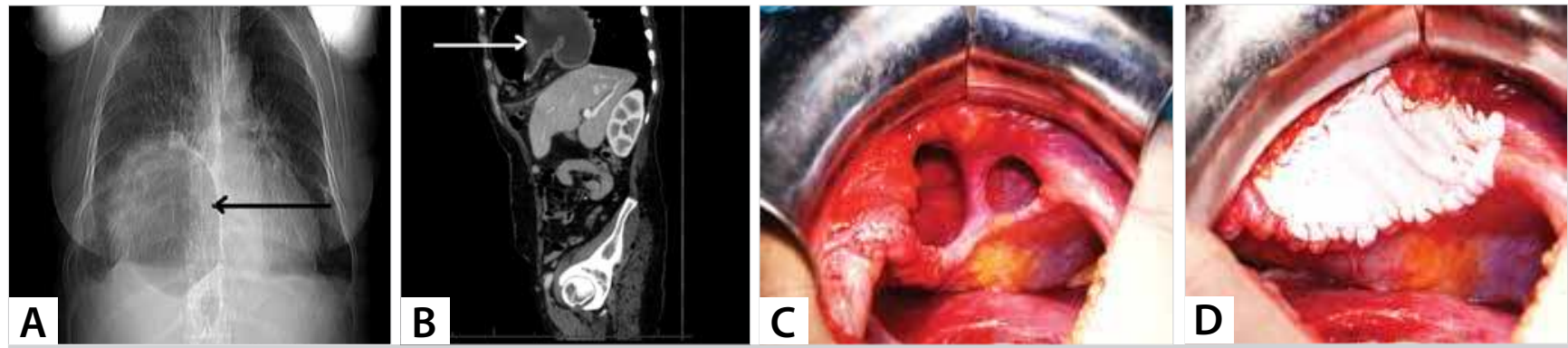

Figure 1. A. Right paracardiac opacity in chest x-ray. B. Herniated stomach in left Morgagni hernia sac. C. Bilateral Morgagni defects. D. Repair with ePTFE mesh.

Post-operatively, the patient did well and was discharged on postoperative day 4. On postoperative day 32, the patient presented with seroma in the repaired defect. The fluid was aspirated under ultrasound guidance. No further complications including recurrent seroma occurred during 63 months of follow up.

\section{Case 2}

A 62-year-old woman was referred from another institute with the diagnosis of Morgagni hernia. Her complaints were dyspnea, nausea, vomiting and episodic right flank pain. Thoracoabdominal CT revealed Morgagni hernia, cholelithiasis and umbilical hernia. The patient was considered for laparoscopic repair. Gastric and omental herniation to the thorax via a 4-cm diaphragmatic unilateral defect was seen in laparoscopic exploration (Figure 2A). The stomach and omentum were reduced into the abdominal cavity, and the diaphragmatic defect was repaired with polypropylene stitches (Figures 2B, 2C and 2D). Hernia sac was not resected, and a silicon drain was placed in the sac. The operation was completed after laparoscopic cholecystectomy and umbilical hernia repair. The patient was discharged on postoperative day 5. She has been followed for 58 months without any complications.

\section{Case 3}

A 63-year-old female patient consulted to the emergency department with abdominal pain, nausea and vomiting. The patient had signs of ileus on abdominal x-ray, and there were no signs of free subdiaphragmatic air but diaphragmatic hernia in chest x-ray. Thoracoabdominal CT revealed ileal and colonic dilatation and diaphragmatic hernia. Exploration through an upper midline incision revealed dilated ileal segments in accordance with the il- eus and a 9-cm unilateral diaphragmatic hernia defect consisting of the omentum and transverse colon. The colon and omentum were reduced into the abdominal cavity, and the diaphragmatic defect was repaired with no.1 polypropylene stitches. The ptient was discharged uneventfully on postoperative day 5. No complication or recurrence was seen in the $44^{\text {th }}$ month of follow up.

\section{Case 4}

A 63-year-old female patient was referred to our clinic with incidentally diagnosed diaphragma hernia in chest x-ray performed for her chest pain. The patient had had gastroesophageal reflux and grade-b esophagitis for 6 years in her medical history. Thoracoabdominal $\mathrm{CT}$ was compatible with Morgagni hernia. Laparoscopic exploration revealed thoracic herniation of transverse colon. Bilateral Morgagni defects of $6 \mathrm{~cm}$ on the right side and 3 $\mathrm{cm}$ on the left side were detected after reducing the colon. Hernia sac was not resected, and the defect was closed with no.1 polypropylene stitches. Laparoscopic nissen fundoplication was performed for gastroesophageal reflux. A silicon drain was placed in the hernia sac, and the operation was completed. The patient was discharged on postoperative day 6 uneventfully. On postoperative day 45 , the patient was admitted with dyspnea. Chest x-ray revealed air-fluid level in the hernia sac and 200 cc seroma was drained with ultrasound guidance. Culture of the aspirated fluid was negative. Seroma did not recur but 6 months later, the patient consulted for dyspnea. Recurrent hernia was detected on thoracoabdominal CT. Open repair with E-PTFE mesh was performed. During the 36 months after second surgery, no further problem was seen.
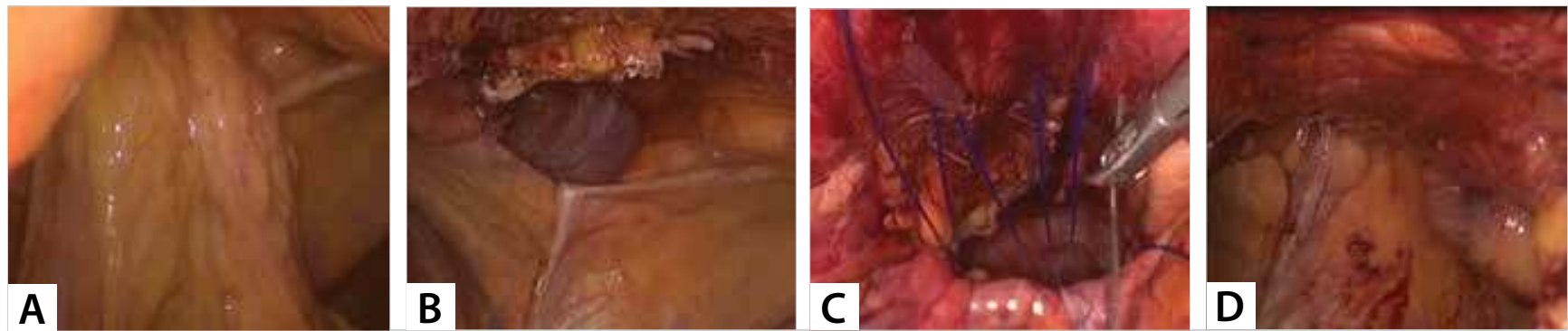

Figure 2. A. Herniated stomach and omentum through a 4-cm diaphragmatic defect. B. Hernia sac was reduced into the abdominal cavity. C. Laparoscopic primary closure of the defect with polypropylene stitches. $\mathbf{D}$. Intraoperative view after primary repair. 


\section{Case 5}

A 51-year-old male patient presented with abdominal distention and vomiting. The patient had hypertension in his medical history. Chest $x$-ray showed air-fluid levels over the diaphragm compatible with herniated intestinal segments to the thorax. Laparoscopy revealed a left Morgagni hernia consisting of the transverse colon. The sac was reduced, and the defect was closed primarily with no.1 polypropylene stitches. A silicone drain was placed in the hernia sac. The patient was discharged on postoperative day 5 and followed up uneventfully during 15 months.

\section{DISCUSSION}

The classical Bochdalek hernia accounts for nearly $80 \%$ of all congenital diaphragm hernias, whereas Morgagni hernia constitutes about $3-4 \%$ of both children and adult diaphragm hernias (3). In Morgagni hernia, the defect is usually small and complaints are related to the size and content of the hernia. The content of the herniation most frequently includes the omentum and colon segments; however, stomach, liver and small intestines might also be herniated (5). Morgagni hernias are right sided in $90 \%$ of the cases, left sided in $8 \%$ and bilateral in $2 \%$ (4). In our cases, three of the 5 patients had unilateral and the other 2 patients had bilateral hernias.

Series have eported that $62 \%$ of the cases are female, and mean age of diagnosis is 53 (5). Four of the five cases were female, and the mean age at diagnosis was 62.6 (51-74) years in our series.

The symptomatology of Morgagni hernia is completely variable; the cases can be asymptomatic or may present with a clinical picture of acute respiratory distress (6). In diaphragmatic hernia cases, a decrease in the respiratory sounds or presence of colonic sounds on chest examination is a significant finding in diagnosis. All of our patients had symptoms related with hernia varying between retrosternal pain and ileus. Chest x-ray and thorax CT are useful in diagnosis (7). Signs in chest $x$-ray may mimic mediastinal mass in some cases with the hernia sac consisting of the omentum alone. We preferred to see thoracoabdominal CT to confirm diagnosis after chest $x$-ray.

Surgery is the curative treatment in Morgagni hernia. Transthoracic, transabdominal and laparoscopic approaches may be performed. Thoracoscopic repair has reported in two patients from the UK (8-9). Laparoscopic approaches are more favored with less complication and hospital stay rates. Open surgery also has some advantages: reduction of the herniated organs is easier. In addition, functional status and circulation of the organs may be evaluated better in open surgery and it also provides to detect a bilateral Morgagni defect easily. Besides thoracic surgery allows easier dissection of mediastinal and pleural adhesions (5,10-11). We performed two transabdominal and 3 laparoscopic surgery.

About 95\% of the Morgagni hernias comprise a hernia sac. Resection of the hernia sac is still controversial. Some authors suggest leaving the sac in order to avoid massive pneumomediastinum and injury of the phrenic nerve (12). Rau et al. have remarked that leaving the sac may result in thoracic cystic lesions and recommended the resection of the hernia sac (13). We preferred to leave the sac in all cases so as to avoid pneumothorax and nerve injury.

In the literature, transabdominal approaches have been performed by primary repair in $88 \%$ of the cases and mesh repair was preferred in 6\%. Primary and mesh repair rates have been reported as 29\% and 64\%, respectively, in laparoscopic approaches (5).

Thoman et al. have suggested that mesh repair may be favorable in defects larger than $20-30 \mathrm{~cm}^{2}$ (14). The results of primary and mesh repairs are similar (5). Recurrence after transthoracic Morgagni hernia repair in adults has been reported in one patient. Other surgical methods have not been reported for recurrence in adults (5), and Case Four in our study is the first recurrence in the literature after laparoscopic repair in the adult group. Recurrence in five of 12 children has been reported in a laparoscopic repair series (15). We performed four primary stitching (3 laparoscopic) and one mesh repair (open transabdominal). Recurrence of a laparoscopic primary repair was restored with open mesh repair.

Complications after transabdominal surgery are pleural effusion, surgical site infection, atelectasis, deep venous thrombosis and pulmonary embolism. Pneumonia and sepsis have been reported after transthoracic surgery. Thirty-day mortality has been reported in four patients after transabdominal surgery (5).

In our patients, mean hospital stay was five days. Thirty-day mortality was not seen. Seroma was seen on postoperative days 32 and 45 in two patients after one transabdominal and one laparoscopic surgery and did not recur after drainage. In our clinical experience, one patient had recurrent hernia after 7 months from laparoscopic surgery (case 4) and we performed open redo repair.

\section{CONCLUSION}

Morgagni hernia is a rare type of hernia especially in adult patients but may cause intestinal obstruction and may present as an emergency due to the strangulation of the herniating viscera. Once diagnosed, surgery should be recommended even in asymptomatic patients in order to prevent the risk of complications. Different surgical techniques can be used efficiently in Morgagni hernia repair, and the choice of surgical procedure is based on peculiar criteria of the patient.

Informed Consent: Written informed consent was obtained from all the patients who participated in this study.

Peer-review: Externally peer-reviewed.

Author Contributions: Concept - C.A., K.A.; Design - C.A., K.A., S.B.; Supervision - C.A., C..A., Z.S.D.; Resource - C.A., K.A., Z.S.D., S.B.; Materials - C.A., K.A., Ç.A.; Data 
Collection and/or Processing - C.A., Ç.A., Z.S.D.; Analysis and/or Interpretation - C.A., C..A.; Literature Search - C.A., K.A., C..A.; Writing Manuscript - C.A., K.A., C..A., Z.S.D., S.B.; Critical Reviews - C.A., S.B.

Conflict of Interest: The authors have no conflicts of interest to declare.

Financial Disclosure: The authors declared that this study has received no financial support.

\section{REFERENCES}

1. LaLaberge JM. Congenital diaphragmatic hernia. In: Nyhus LM, Condon R (eds). Hernia. $4^{\text {th }}$ ed. Philadelphia: JB Lippincott, 1995:555-66.

2. Federico JA, Ponn RB. Foramen of Morgagni hernia. In: Shields TW, LoCicero III J, Ponn RB (eds). General Thoracic Surgery. Philadelphia: Lippincott Williams and Wilkins, 2000:647-50.

3. Paris F, Tarazona V, Casillas M, Blasco E, Cantó A, Pastor J, et al. Hernia of Morgagni. Thorax 1973;28:631-6.

4. Comer TP, Clagett OT. Surgical treatment of hernia of the foramen of Morgagni. J Thorac Cardiovasc Surg 1966;52:461-8. [CrossRef]

5. Horton JD, Hofmann LJ, Hetz SP. Presentation and management of Morgagni hernias in adults: a review of 298 cases. Surg Endosc 2008;22:1413-20. [CrossRef]

6. Wong NA, Dayan CM, Virjee J, Heaton KW. Acute respiratory distress secondary to Morgagni diaphragmatic herniation in an adult. Postgrad Med J 1995;71:39-41. [CrossRef]

7. Gossios KJ, Tatsis CK, Lykouri A, Constantopoulos SH. Omental herniation through the foramen of Morgagni. Diagnosis with chest computed tomography. Chest 1991;100:1469-70. [CrossRef]
8. Akamine S, Kawahara K, Nakamura A, Takahashi T, Yamamoto $S$, Ayabe $H$, et al. Successful utilization of a video assisted thoracics (VATS) approach to repair Morgagni's hernia: report of a case. Surg Today 1995;25:654-6. [CrossRef]

9. Hussong RL, Landreneau RJ, Cole FH. Diagnosis and repair of a Morgagni hernia with video assisted tho racic surgery. Ann Thorac Surg 1999;63:1474-5. [CrossRef]

10. Slaetis P. Herniation through the foramen of Morgagni: clinical observations in 17 operatively treated cases. Ann Chir Gynaecol Fenn 1963;52:477-86.

11. Loong TPF, Kocher HM. Clinical presentation and operative repair of hernia of Morgagni. Postgrad Med J 2005;81:41-4. [CrossRef]

12. Orita M, Okino M, Yamashita K, Morita N, Esato K. Laparoscopic repair of a diaphragmatic hernia through the foramen of Morgagni. Surg Endosc 1997;11:668-70. [CrossRef]

13. Rau HG, Schardey HM, Lange V. Laparoscopic repair of a Morgagni hernia. Surg Endosc 1994;8:1439-42. [CrossRef]

14. Thoman DS, Hui T, Phillips EH. Laparoscopic diaphragmatic hernia repair. Surg Endosc 2002;16:1345-9. [CrossRef]

15. Garriboli M, Bishay M, Kiely EM, Drake DP, Curry JI, Cross KM, et al. Recurrence rate of Morgagni diaphragmatic hernia following laparoscopic repair. Pediatr Surg Int 2013;29:185-9. [CrossRef]

\title{
OLGU SERISI-ÖZET
}

Turk J Surg 2019; 35 (4): 321-324

\section{Erişkin Morgagni hernileri: tek merkezden 5 olguluk deneyim ve literatürün gözden geçirilmesi}

\author{
Cihan Ağalar ${ }^{1}$, Koray Atila ${ }^{1}$, Naciye Çiğdem Arslan ${ }^{2}$, Zekai Serhan Derici ${ }^{1}$, Seymen Bora ${ }^{1}$ \\ ${ }^{1}$ Dokuz Eylül Üniversitesi Tıp Fakültesi, Genel Cerrahi Anabilim Dalı, İzmir, Türkiye \\ ${ }^{2}$ Istinye Üniversitesi Tıp Fakültesi, Genel Cerrahi Anabilim Dalı, Istanbul, Türkiye
}

\section{ÖZET}

Morgagni hernisi nadir olarak karşılaşılan; bir konjenital anomali olup septum transversum ve sternum arasındaki yetersiz füzyon sonucunda oluşur. Tanısı oldukça güçtür, hastalar asemptomatik olabileceği gibi solunum sistemine ait şikayetler, ağrı, dolgunluk hissi ve gastrointestinal sisteme ait obstruksiyon bulgularıyla başvurabilirler. Bu olgu serisinde Morgagni hernisi nedeniyle 2009-2015 yılları arasında kliniğimizde üçü laparoskopik, ikisi açık yöntemle opere edilen beş olgumuz sunulmuştur. Laparoskopik onarım sonrası bir hastamızda yedinci ayda nüks gelişmiştir, bu olgu literatürdeki erişkin gruptaki ilk laparoskopik onarım sonrası nüks olması nedeniyle önemlidir. Morgagni hernilerinde tek tedavi seçeneğ ameliyattır. Cerrahi transtorakal, transabdominal, laparoskopik veya torakoskopik olarak uygulanabilir. Meş kullanımı ve herni kesesinin çıkarılması konularında tartışma sürmektedir.

Anahtar Kelimeler: Morgagni fıtığı, diyafram fıtığı, laparoskopik onarım

Doi: $10.5578 /$ turkjsurg.3929 